\title{
Activation of peroxisome proliferator- activated receptor gamma induces anti-inflammatory properties in the chicken free avian respiratory macrophages
}

\author{
Mbuvi P. Mutua ${ }^{1 *} \mathbb{D}$, Lucilla Steinaa ${ }^{2}$, Muya M. Shadrack ${ }^{3}$ and Gicheru M. Muita ${ }^{1}$
}

\begin{abstract}
Background: Activation of peroxisome proliferator activated receptor gamma (PPAR $\gamma$ ) in the alveolar macrophages (AM) by selective synthetic PPAR $y$ ligands, improves the ability of the cells to resolve inflammation. In birds, respiratory macrophages are known as free avian respiratory macrophages (FARM) and show distinct functional differences from AM. The effects of treating FARM with PPAR $\gamma$ ligands are unclear.

Methods: FARM were harvested by lavage of chicken respiratory tract and their morphology assessed at microscopic level. The effects of PPAR $y$ agonists on the FARM in vitro viability, phagocytic capacity and proinflammatory cytokine (TNF-a) production were assessed.

Results: FARM had eccentric nucleus and plasma membrane ruffled with filopodial extensions. Ultrastructurally, numerous vesicular bodies presumed to be lysosomes were present. FARM treated with troglitazone, a selective PPAR $y$ agonist, had similar in vitro viability with untreated FARM. However, treated FARM co-cultured with polystyrene particles, internalized more particles with a mean volume density of $41 \%$ compared to that of untreated FARM of $21 \%$. Further, treated FARM significantly decreased LPS-induced TNF-a production in a dose dependent manner.

Conclusion: Results from this study show that PPAR $y$ synthetic ligands enhance phagocytic ability of FARM. Further the ligands attenuate production of proinflammatory cytokines in the FARM, suggesting potential therapeutic application of PPAR $y$ ligands in the management of respiratory inflammatory disorders in the poultry industry.
\end{abstract}

Keywords: Avian, Free avian respiratory macrophages, Peroxisome proliferator-activated receptor, Troglitazone

\section{Background}

Alveolar macrophages (AM) in mammals constitute first line of pulmonary defense where they expunge deposited foreign particles and kill pathogens that land on the vast and thin gas-blood tissue barrier [1]. Following infections, activated AM produce proinflammatory cytokines and other mediators of inflammation that serve to localize and remove injurious stimuli [2]. However, prolonged inflammation is maladaptive and is characterized

\footnotetext{
* Correspondence: patmbuvi@gmail.com

${ }^{1}$ Department of Zoological Sciences, Kenyatta University, P.O Box 43844-00100, Nairobi, Kenya

Full list of author information is available at the end of the article
}

by persistent production of proinflammatory cytokines augmenting respiratory epithelial tissue damage [3].

Peroxisome proliferator activated receptors (PPAR) are ligand activated transcription factors and three isoforms, PPAR $\alpha, \operatorname{PPAR} \delta$ and PPAR $\gamma$ have been described [4]. The PPAR show distinct tissue distribution $[5,6]$ with PPAR $\gamma$ being predominantly expressed in adipose tissue where it plays an important role in glucose metabolism and adipogenesis [7]. Expression of PPAR $\gamma$ protein has also been demonstrated in monocytes and macrophages [8]. Thiazolidinediones are selective synthetic PPAR $\gamma$ agonists $[9,10]$ which improve the ability of AM to restore alveolar architecture through non phlogistic 
clearance of inflammatory sites in the mammalian lung $[11,12]$. Chicken peroxisome proliferator activated receptor gamma (chPPAR $\gamma$ ) is structurally different from the mammalian PPAR $\gamma$ suggesting different functional roles $[13,14]$.

Respiratory disease conditions, partly characterized by chronic inflammation of the respiratory epithelia, cause immense economic losses in the poultry industry [15, 16]. Despite the losses, relatively little is known about the avian pulmonary cellular defense mechanisms [17, 18]. In birds, respiratory macrophages are referred to as free avian respiratory macrophages (FARM) $[19,20]$ and dearth of the cells in the lung air sac system has been purported to foreordain a weak innate immunity thus predisposing birds to respiratory inflictions [21-23]. However, FARM exhibit a significantly higher phagocytic ability than AM [24] and mobilization of the cells in the avian respiratory system does not occur after intravenous application of lipopolysaccharide, incomplete freunds adjuvant or glucan, compounds known to induce migration of AM from the lung interstitium into the alveolar space [25].

The effects of PPAR $\gamma$ agonists on FARM are unknown. The aim of this study was, therefore, to determine:

(i) The effect of selective synthetic PPAR $\gamma$ ligands on the phagocytic capacity of FARM

(ii) The effect of the PPAR $\gamma$ ligands on proinflammatory cytokine production by assessing TNF- $\alpha$ secretion in lipopolysaccharide activated FARM.

\section{Methods}

\section{Pulmonary lavage of the avian respiratory system}

All experimental procedures were approved by the Kenyatta University Animal Ethics Committee. FARM were obtained from the respiratory system of mature specimens of domestic fowl as previously described [26]. Briefly, chickens were anesthetized and then euthanized by intravenous injection of an overdose of pentobarbitone sodium (Euthanase ${ }^{\circ}$ ) into the brachial vein. The trachea was then exposed and sterile pre-warmed $\left(40{ }^{\circ} \mathrm{C}\right)$ phosphate buffered saline (PBS) was poured down the respiratory system. Recovered lavage fluid was centrifuged and the pelleted FARM re-suspended in sterile cellculture medium.

\section{Processing of FARM for transmission electron microscopy (TEM)}

Recovered FARM were fixed in $2.5 \%$ phosphate buffered glutaraldehyde solution for $12 \mathrm{~h}$. The cells were then post fixed in $1 \%$ osmium tetraoxide in $0.1 \mathrm{M}$ sodium cacodylate buffer followed by dehydration in graded replacement of ethanol (70 \%, $80 \%, 90 \%$, and $100 \%$ twice). Gradual replacement of ethanol with propylene oxide was then done before infiltrating and embedding the cells in epoxy resin. Using Reichter ultra-microtome, semithin and ultrathin sections were obtained from processed blocks. The semithin sections were collected on glass slides and stained with $3 \%$ toluidine blue while the ultrathin sections were picked on copper grids, stained with uranyl acetate and lead citrate, and observed with a Philips 201C TEM under an accelerating voltage of $60 \mathrm{Kv}$. Micrographs were developed from the processed sections for morphological studies.

\section{In vitro viability of the FARM}

FARM were washed three times in PBS and re-suspended at a concentration of $1.5 \times 10^{5}$ cells $/ \mathrm{ml}$ in sterile eppendorf tubes containing RPMI-1640 cell culture medium and treated with $9 \mu \mathrm{M}$ of troglitazone (Abcam, Science Park Cambridge, UK) for $1 \mathrm{~h}$. A control pellet of FARM was processed in a similar manner but without troglitazone. The tubes were kept for $4 \mathrm{~h}$ in an incubator $\left(40{ }^{\circ} \mathrm{C}\right.$ and $5 \% \mathrm{CO}_{2}$ ). A viable count of FARM was assessed using trypan blue in hemocytometer.

\section{Phagocytosis assays}

Recovered FARM were re-suspended at concentrations of $1.5 \times 10^{5}$ cells $/ \mathrm{ml}$ in fresh RPMI - 1640 in sterile eppendorf tubes. The FARM were treated with $9 \mu \mathrm{M}$ of troglitazone in incubator for $1 \mathrm{~h}$. Treated and untreated

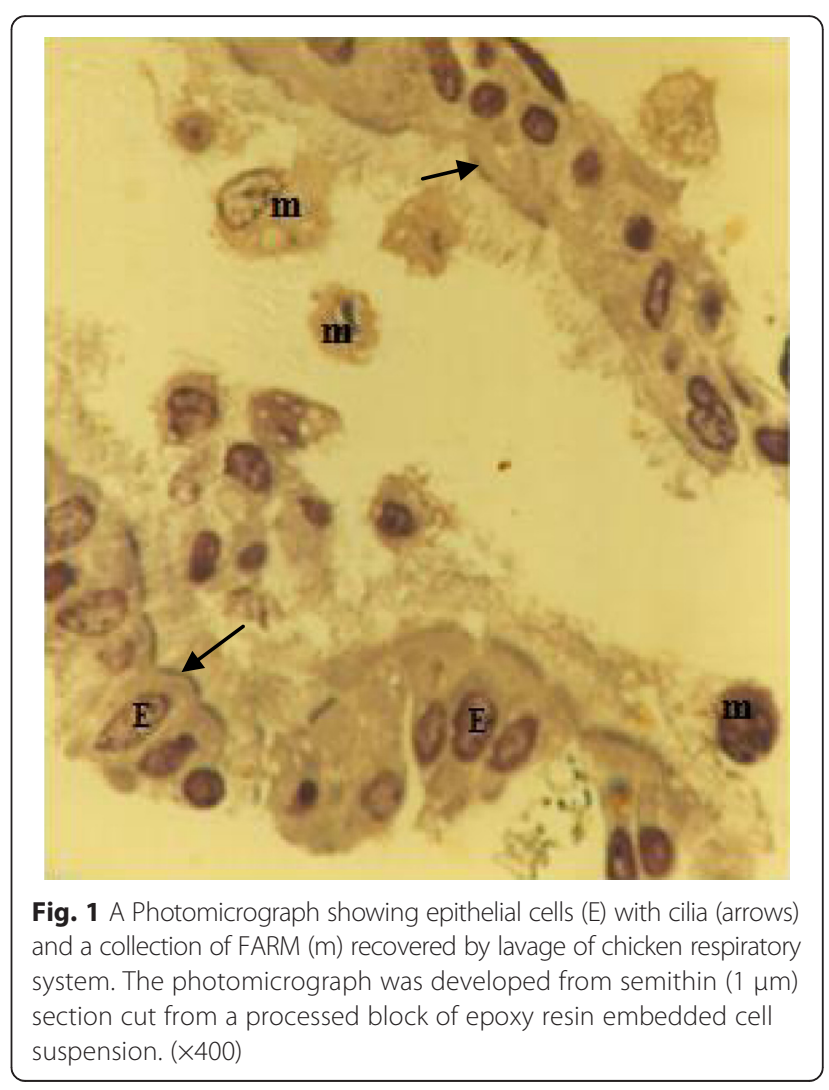



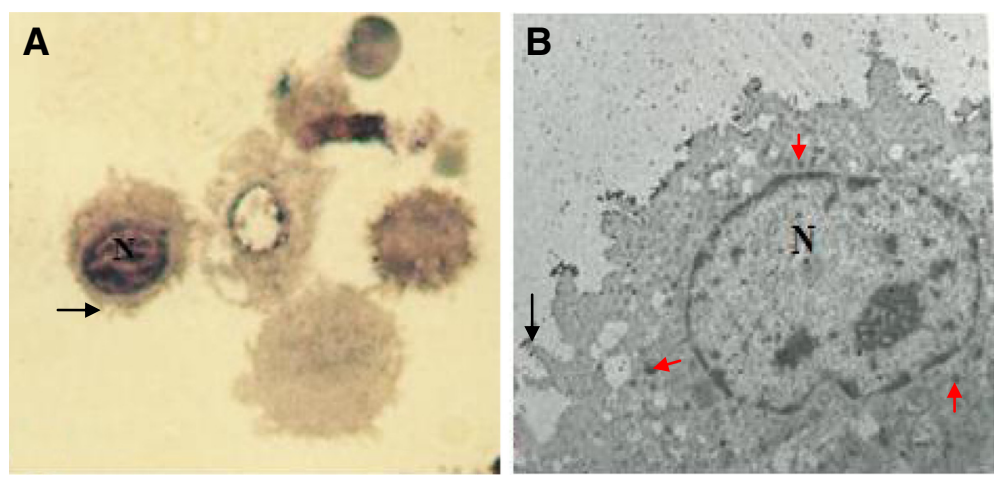

Fig. 2 a Photomicrograph (×400) and (b) electron micrograph (×950) of FARM recovered by lavage of the chicken respiratory system. The cells have eccentric nucleus (N) and plasma membrane ruffled with filopodial extensions (arrows). In (b), numerous cytoplasmic vesicular bodies presumed to be lysosomes (red arrows) were identified. The Semithin $(1 \mu \mathrm{m})$ and the ultrathin $(80 \mathrm{~nm})$ sections were cut from processed blocks of epoxy resin embedded cell suspensions

FARM were co-cultured with polystyrene particles (Sigma 3050 Spruce Street, USA) in incubator for $3 \mathrm{~h}$. Shaking of tubes was done regularly to ensure contact of the cells and the particles. Thereafter, FARM were fixed in $2.5 \%$ phosphate buffered glutaraldehyde solution for $12 \mathrm{~h}$ and processed for TEM. Semithin and ultrathin sections were processed for estimation of diameter of the FARM and volume density of internalized particles in the cells respectively.

\section{Estimation of the diameters of the FARM and the volume density of the phagocytized particles}

Diameters of FARM were determined under an ocular graticule with a linear scale at a magnification of $\times 100$. In each field, to avoid bias, only diameters of FARM at the four corners of the fields were measured. The volume density of the phagocytized particles in the FARM was estimated as previously described [27]. Briefly, ultrathin sections were processed and the corresponding micrographs recorded on a 35-mm electron microscope film prior to being projected onto a screen at a final magnification of $\times 14000$. A quadratic lattice grid was superimposed at a random position onto each projected image. The total number of points falling onto profiles of the phagocytized particles $[\mathrm{P}(\mathrm{p})]$ and on entire cell $[\mathrm{P}$ (c)] was counted. Volume density of phagocytized particles $[\mathrm{V} \mathrm{V}(\mathrm{p}, \mathrm{c})]$ was then calculated as follows: $\mathrm{V} \mathrm{V}$ $(\mathrm{p}, \mathrm{c})=\mathrm{P}(\mathrm{p}) / \mathrm{P}(\mathrm{c})$

\section{Measurement of TNF-a production by the FARM}

The FARM were washed three times in PBS and seeded at a density of $1.5 \times 10^{5}$ cells/well in RPMI 1640 with $5 \%$ FCS into 24-well tissue culture. The cells were treated with varying doses $(3 \mu \mathrm{M}, 6 \mu \mathrm{M}$ and $9 \mu \mathrm{M})$ of troglitazone for $1 \mathrm{~h}$ before addition of $0.1 \mathrm{ng} / \mathrm{ml}$ lipopolysaccharide (LPS). After $24 \mathrm{~h}$ incubation at $40{ }^{\circ} \mathrm{C}$ in $5 \% \mathrm{CO}_{2}$, the supernatants were harvested for TNF- $\alpha$ measurement using ELISA kit (Bicom Biotech, SA). Briefly, the supernatants were diluted appropriately and incubated with anti-chicken TNF- $\alpha$ antibody coated plate at $40{ }^{\circ} \mathrm{C}$ for $1 \mathrm{~h}$. The plate was washed 3 times in phosphate buffered saline-tween (PBS-T) followed by addition of biotin-streptavidin HRP labeled anti-chicken TNF- $\alpha$. The plate was incubated for $30 \mathrm{~min}$ at $40{ }^{\circ} \mathrm{C}$ followed by 3 washes in PBS-T before addition of chromogen.

\section{Data analysis}

For paired experiments, student $t$-test was used to compare the values on the chicken FARM in the various experiments while analysis of group data for multiple comparisons was performed using ANOVA followed by Duncan's multiple range test to determine the level of differences. The level of significance was set at $p \leq 0.05$ confidence level. The results were presented in form of tables, graphs and micrographs. Means \pm Standard Error

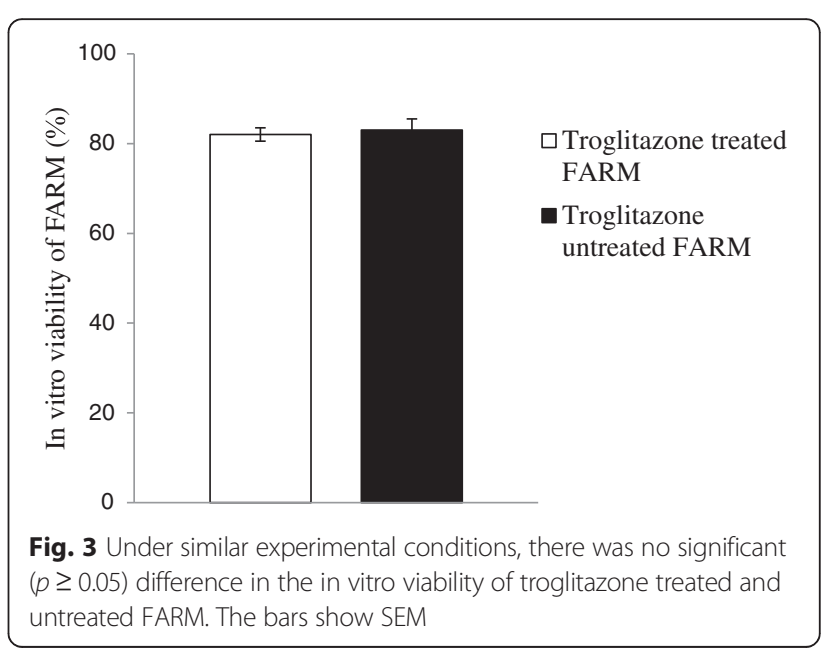


Table 1 Mean diameter of troglitazone treated and untreated

\begin{tabular}{lll} 
FARM & & \\
\hline Slide Number & $\begin{array}{l}\text { Diameter of treated } \\
\text { FARM }(\mu \mathrm{m})\end{array}$ & $\begin{array}{l}\text { Diameter of untreated } \\
\text { FARM }(\mu \mathrm{m})\end{array}$ \\
\hline 1 & 12 & 14 \\
2 & 15 & 10 \\
3 & 12 & 11 \\
4 & 11 & 12 \\
5 & 13 & 12 \\
6 & 10 & 10 \\
7 & 11 & 13 \\
8 & 9 & 13 \\
9 & 14 & 11 \\
10 & 12 & 12 \\
11 & 10 & 11 \\
12 & 12 & 13 \\
Mean & 11.7 & 11.8 \\
SEM & 0.5 & 0.4 \\
\hline
\end{tabular}

Data represent the mean diameter of troglitazone treated and untreated FARM that were co-cultured with polystyrene particles. The mean diameter of treated FARM was not significantly $(p \geq 0.05)$ different from that of untreated FARM

of the Mean (SEM) were used to explain the results in text and tables.

\section{Results}

\section{Morphological observations}

The lavage fluid recovered from the respiratory system of the chicken contained both ciliated epithelial cells and FARM (Fig. 1). Typically, the FARM had plasma membrane ruffled with filopodial extensions and an eccentrically located nucleus (Fig. 2). Ultra structurally, the FARM had variably electron dense vesicular cytoplasmic organelles presumed to be lysosomes (Fig. 2b)

\section{In vitro viability of the FARM}

Troglitazone treatment of chicken FARM at a dosage of $9 \mu \mathrm{M}$ for $4 \mathrm{~h}$ did not compromise FARM viability. Troglitazone treated FARM exhibited equivalent $(p \geq 0.05)$ in vitro viability with untreated FARM under similar experimental conditions. The in vitro viability of troglitazone treated FARM and untreated FARM was $82 \pm 1.5 \%$ and $83 \pm 2.5 \%$ respectively (Fig. 3 ).

\section{Morphometric observations}

The mean diameter of troglitazone treated FARM was not significantly $(P \geq 0.05)$ different from that of untreated FARM (Table 1). Quantitative estimation of loading of FARM with polystyrene particles was assessed using micrographs (Figs. 4 and 5). Despite having equivalent diameters and therefore volume, the mean volume density of internalized particles per unit volume of treated FARM was $41 \pm 1.0 \%$, a significant $(P \leq 0.05)$ value compared to that of the untreated FARM which was $21 \pm 1.1 \%$ (Fig. 6).

\section{The effect of troglitazone on TNF- a production by the chicken FARM}

To define the functional role of PPAR- $\gamma$ in the chicken FARM, the effect of troglitazone on cytokine production by the chicken FARM was measured by determining TNF- $\alpha$ concentrations in culture supernatants of lipopolysaccharide-stimulated FARM after treatment with graded $(3 \mu \mathrm{M}, 6 \mu \mathrm{M}$ and $9 \mu \mathrm{M})$ doses of troglitazone. Lipopolysaccharide elicited considerable amounts of TNF$\alpha$ production by FARM at concentration of $0.1 \mathrm{ng} / \mathrm{ml}$. Addition of troglitazone to cultures of LPS-induced chicken FARM, significantly $(p \leq 0.05)$ inhibited TNF- $\alpha$ production by the FARM in a dose dependent manner (Fig. 7).

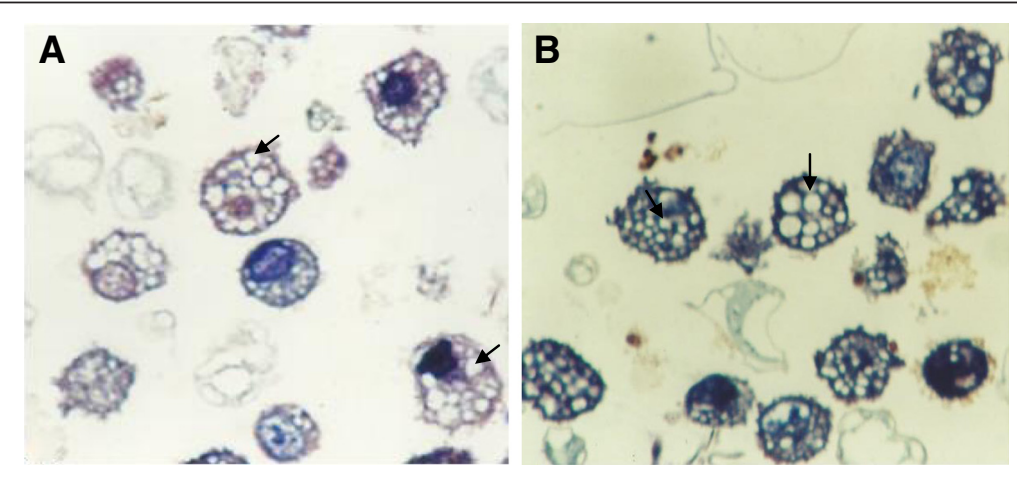

Fig. 4 Photomicrographs showing internalized polystyrene based particles (arrows) in (a) troglitazone untreated FARM and (b) troglitazone treated FARM (b). The FARM and the particles were co-cultured in RPMI 1640 culture medium for $3 \mathrm{~h}$. The photomicrographs were prepared from semithin $(1 \mu \mathrm{m})$ sections cut from processed blocks of epoxy resin embedded cell suspension. ( $\times 400)$ 

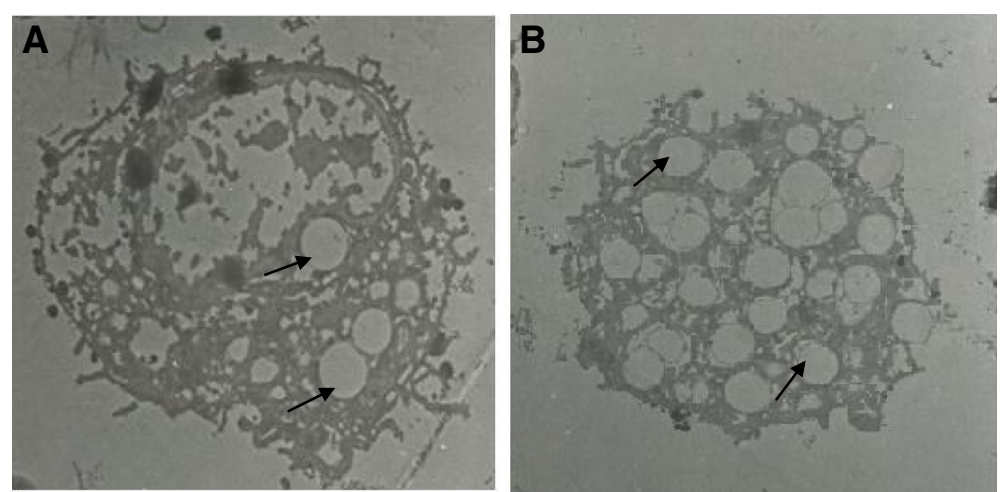

Fig. 5 Electron micrographs showing internalized polystyrene particles (arrows) in (a) troglitazone untreated and (b) troglitazone treated chciken FARM. Three and twenty partciles have been phagocytozed in (a) and (b) respectively. In (b) the particles are engulfed in irregular vacoules presumably an indication of enhanced destruction of internalized particles. The micropraphs were developed from ultrathin (80 nm) sections cut from blocks of epoxy resin embedded cell suspension. (x950)

\section{Discussion}

In the present study, we examined the effect of PPAR $\gamma$ ligands on the phagocytic capacity of FARM. This study reports for the first time that the phagocytic capacity of freshly harvested chicken FARM is enhanced by selective synthetic PPAR $\gamma$ ligands. Selective synthetic PPAR $\gamma$ ligands improve the phagocytic ability of AM with subsequent clearance of inflammatory site, an essential process during restoration of alveolar architecture in the mammalian lung [28]. Chronic inflammation, partly characterized by accumulation of FARM with diminished phagocytic ability in the inflammatory site, causes gross respiratory epithelial tissue destruction with subsequent high mortality in the poultry industry $[29,30]$. Phagocytosis is the most important defense mechanism in all phyla of the animal kingdom [31] and therefore, up regulation of phagocytic ability of FARM by PPAR $\gamma$ agonists could be critical in clearance of inflammatory stimuli in the avian lung. In this study, PPAR $\gamma$ ligands

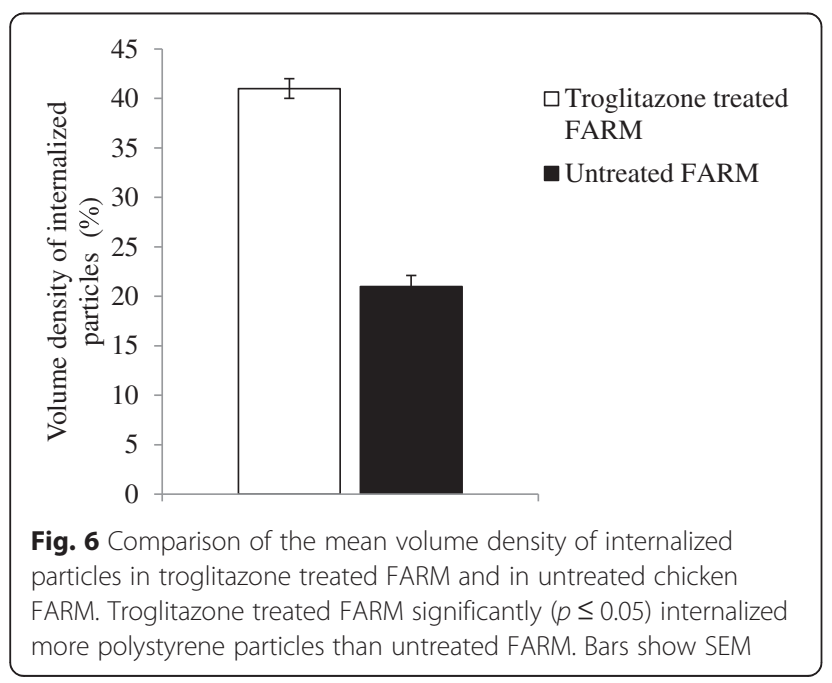

substantially improved the phagocytic ability FARM. Further, troglitazone treated FARM had irregular vacuoles formed around ingested particles indicating up regulated destruction of internalized particles by the FARM.

A characteristic of non phlogistic phagocytosis is the ability of activated macrophages to clear inflammatory stimuli with diminished production of proinflammatory cytokines [32]. To elucidate the non phlogistic functional role of PPAR $\gamma$ ligands during phagocytosis in the FARM, we treated lipopolysaccharide activated FARM with varying doses of troglitazone. Troglitazone treated FARM inhibited TNF- $\alpha$ production in lipopolysaccharide activated FARM in a dose dependent manner. TNF- $\alpha$ has been reported as the primary regulator of inflammation [33] and activated FARM produce TNF- $\alpha$ in response to respiratory inflictions [34]. However, incessant production of proinflammatory cytokines prolongs inflammation contributing to pathogenesis of respiratory disease conditions such as aspergillosis [35]. An understanding of the

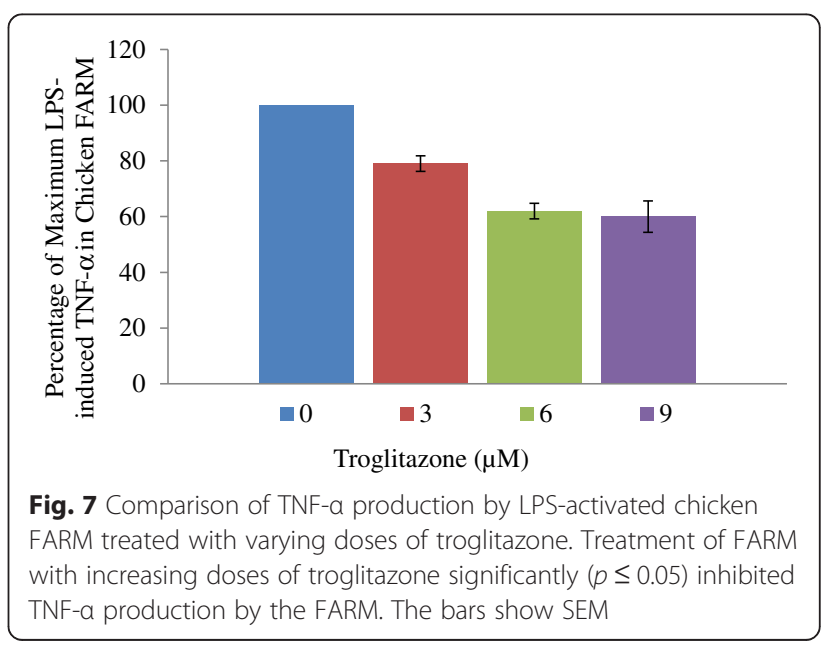


mechanisms that enhance FARM to regulate inflammatory responses may permit development of products for the enhancement productivity in the poultry industry. FARM are the predominant immune cells in the avian lung [36] therefore, synthetic PPAR $\gamma$ agonists could be used in attenuating proinflammatory cytokine production by the cells as a therapeutic intervention in resolving respiratory inflammatory disease conditions in the poultry industry.

\section{Conclusion}

In this study, selective synthetic PPAR $\gamma$ agonists significantly enhanced the phagocytic index of chicken FARM. Further, the PPAR $\gamma$ ligands attenuated production of proinflammatory cytokine TNF- $\alpha$ by activated FARM. This study, therefore, concludes that PPAR $\gamma$ ligands are attractive therapeutic novel drug targets for resolution of avian respiratory inflammatory disease conditions.

\section{Competing interests}

The authors declare that they have no competing interests.

\section{Authors' contributions}

Mutua M. Patrick carried out the experiments and prepared the manuscript as part of his PhD (Immunology) research project. All authors read and approved the final manuscript draft.

\section{Acknowledgement \\ We are grateful to Louise Bowditch, Boston, USA for funding this research project. Excellent technical support was provided by Peter Kiguru from the Department of Veterinary Anatomy and Physiology, Chiromo campus, University of Nairobi and Piera Muthoni Ireri from the Department of Zoological Sciences, Kenyatta University, Nairobi.}

\section{Author details}

${ }^{1}$ Department of Zoological Sciences, Kenyatta University, P.O Box 43844-00100, Nairobi, Kenya. ${ }^{2}$ International Livestock Research Institute, P.O Box 30709-00100, Nairobi, Kenya. ${ }^{3}$ Department of Zoology, Jomo Kenyatta University of Agriculture and Technology, P.O Box 62000-0200, Nairobi, Kenya.

Received: 10 July 2015 Accepted: 15 November 2015

Published online: 20 November 2015

\section{References}

1. Geiser M, Baumann M, Cruz-Orive LM, Hof V, Waber U, Gehr P. The effect of particle inhalation on macrophage number and phagocytic activity in the intrapulmonary conducting airways. Am J Respir Cell Mol Biol. 2002;10:594-603.

2. Kumar $V$, Sharma A. Neutrophils: Cinderella of innate immune system. Int Immunopharmacol. 2010;10:1325-34.

3. Yan Y, Gang H, Erran L, Qiuyue W, Jian K. PPAR Gamma agonists regulate tobacco smoke - induced toll like receptor 4 expression in alveolar macrophages. Respir Res. 2014;15:1-14.

4. Desvergne B, Wahli W. Peroxisome proliferator Activated Receptors: Nuclear control of Metabolism. Endocr Rev. 1999;20:649-88.

5. Kliewer SA, Forman BM, Blumberg B, Ong ES, Borgmeyer U, Mangelsdorf DJ, et al. Differential expression and activation of a family of murine peroxisome proliferator-activated receptors. Proc Natl Acad Press USA. 1994;91:7355-9.

6. Braissant O, Foufelle F, Scotto C, Dauca M, Wahli W. Differential expression of peroxisome proliferator-activated receptors (PPARs): tissue distribution of PPAR- $\alpha,-\delta$, and $-\gamma$ in the adult rat. Endocrinology. 1996;137:354-66.

7. Chawla A, Schwarz EJ, Dimaculangan DD, Lazar MA. Peroxisome proliferatoractivated receptor (PPAR) $\gamma$ : adipose-predominant expression and induction early in adipocyte differentiation. Endocrinology. 1994;135:798-800.
8. Kazuhiro A, Shigekazu S, Takafumi S, Kingo C, Hirotoshi N. Antiinflammatory Roles of Peroxisome Proliferator Activated Receptor $\gamma$ in Human Alveolar Macrophages. Am J Respir Crit Care Med. 2004;169:195-200.

9. Lehmann JM, Moore LB, Smith-Oliver TA, Wilkison WO, Willson TM, Kliewer SA. An antidiabetic thiazolidinedione is a high affinity ligand for peroxisome proliferator-activated receptor $\gamma$ (PPAR $\gamma$ ). J Biol Chem. 1995;270:1295-312956.

10. Willson TM, Cobb JE, Cowan DJ, Wiethe RW, Correa ID, Prakash SR, et al. The structure- activity relationship between peroxisome proliferator-activated receptor $\gamma$ agonism and the antihyperglycemic activity of thiazolidinediones. J Med Chem. 1996;39:665-8.

11. Jiang C, Ting AT, Seed B. PPAR-gamma agonists inhibit production of monocyte inflammatory cytokines. Nature. 1998;391:82-6.

12. Catherine $G$, Siobhan M, Killeen H, Nicos AP, Nancy H, Hugh RB. Lipoxins Rapidly Stimulate Nonphlogistic Phagocytosis of Apoptotic Neutrophils by Monocyte Derived Macrophages. J Immunol. 2000;164:1663-7.

13. Takada I, Kobayashi M. Structural features and transcriptional activity of chicken PPARs ( $\alpha, \beta$ and $\gamma$ ). PPAR Res. 2013;2012:1-7.

14. Sato K, Fukao K, Seki Y, Akiba Y. Expression of the chicken PPAR-gamma gene is influenced by aging, nutrition, and agonist administration. Poult Sci. 2004:83:1342-7.

15. Currie RJW. Ascites in poultry: recent investigations. Avian Pathol. 1999;28:313-26.

16. Sultana S, Rashid SMH, Islam MN, Ali MH, Azam MG. Pathological Investigation of Avian Aspergillosis in Commercial Broiler Chicken at Chittagong District. Int J Innov Appl Stud. 2015;10:366-76.

17. Golemboski KA, Whelan J, Shaw S, Kinsella JE, Dietert PR. Avian inflammatory Macrophage Function: Shifts in Arachidonic Acid Metabolism, Respiratory Burst, and Cell- Surface Phenotype During Response to Sephadex. J Leukoc. 1990;48:495-501.

18. Brown RE, Brain JD, Wang N. The avian respiratory system: a unique model for studies of respiratory toxicosis and for monitoring air quality. Environ Health Perspect. 1997;105:188-200.

19. Reese SG, Dalamani T, Kaspers B. The avian lung - immune system: a review. J Cell Biol. 2006;37:311-24.

20. Fulton RM, Reed WM, DeNicola DB. Light microscopic and ultra-structural characterization of cells recovered by respiratory lavage of 2 and 6 week old chickens. Avian Dis. 1990;34:87-109.

21. Toth TE. Nonspecific cellular defense of the avian respiratory system: a review. Dev Comp Immunol. 2000;24:121-39.

22. Kiama SG, Adekunle JS, Maina JN. Comparative in vitro study of interactions between particles and respiratory surface macrophages, erythrocytes, and epithelial cells of the chicken and the rat. J Anat. 2008;213:452-63.

23. Maina JN, Cowley HM. Ultra-structural characterization of the pulmonary cellular defenses in the lung of a bird, the rock dove, Columbia livia. Royal Society London. 1998;256:1567-72.

24. Mutua PM, Gicheru MM, Makanya AN, Kiama SG. Comparative quantitative and qualitative attributes of free surface respiratory macrophages in the duck and rabbit. Int J Morphol. 2011;2:353-62.

25. Nganpiep L, Maina JN. Composite cellular defense stratagem in the avian respiratory system: functional morphology of the free surface macrophages and specialized pulmonary epithelia. J Anat. 2002;200:499-516.

26. Toth $T E$, Siegel PB. Cellular defense for the avian respiratory tract: paucity of free residing macrophages in the normal chicken. Avian Dis. 1986;30:67-75.

27. Gundersen HJG. Notes on the estimation of the numerical density of arbitrary profiles: the edge effect. J Microsc. 1977;111:219-23.

28. Krey G, Braissant O, L'Horset F, Kalkhoven E, Perroud M, Parker MG, et al. Fatty acids, eicosanoids, and hypolipidemic agents identified as ligands of peroxisome proliferator-activated receptors by coactivator-dependent receptor ligand assay. Mol Endocrinol. 1997;11:779-91.

29. Nagy L, Tontonoz P, Alvarez JGA, Chen H, Evans RM. Oxidized LDL regulates macrophage gene expression through ligand activation of PPAR $\gamma$. Cell. 1998;93:229-40.

30. Van Waeyenberghe L, Frank P, Katharina D, Richard D, Harman F, Shao-J L. Germination of Aspergillus fumigatus inside avian respiratory macrophages is associated with cytotoxicity. Vet Res. 2012;43:1-5.

31. Nicod LP. Lung defenses: an overview. Eur Respir Rev. 2005;14:45-50.

32. Peter KKW, Ian KC, Paul JE, Mathias E, lan PW. The Role of the Interleukin-6 Family of Cytokines in Inflammatory Arthritis and Bone Turnover. Arthritis Rheum. 2003;48:1177-89. 
33. Zhang SP, Lillehoj HS, Ruff MD. In vivo role of tumor necrosis like factors in Eimeria tenella infection. Avian Dis. 1995;39:859-66.

34. Klasing K. Avian inflammatory response mediation by macrophages. Poult Sci. 1991;70:1176-86.

35. Pascal A, Simon T, Dongying W, Manjula D, Guillaume L. Aspergillus fumigates in poultry. Int J Microbiol. 2011;2011(10):1-14.

36. Maina JN. Some recent advances on the study and understanding of the functional design of the avian lung: morphological perspectives. Biol Rev Camb Philos Soc. 2002;77:97-152.

Submit your next manuscript to BioMed Central and we will help you at every step:

- We accept pre-submission inquiries

- Our selector tool helps you to find the most relevant journal

- We provide round the clock customer support

- Convenient online submission

- Thorough peer review

- Inclusion in PubMed and all major indexing services

- Maximum visibility for your research 